\title{
Functions of Gastronomic Images in the Novel Ni Ève, Ni Adam by Amélie Nothomb
}

\author{
Tetiana Cherkashyna ${ }^{1}{ }^{*}$ Simona Mercantini ${ }^{1}$ Mariia Bieliavska ${ }^{1}$
}

\author{
Anna Satanovska ${ }^{1}$ \\ ${ }^{1}$ Department of Roman Philology and Translation, V. N. Karazin Kharkiv National University, Ukraine \\ *Corresponding author. Email: tetiana.cherkashyna@,karazin.ua
}

\begin{abstract}
The article analyses problems of intercultural communication through the prism of gastronomic images. The study is based on the novel Ni Eve, ni Adam by the Modern French-speaking Belgian writer Amélie Nothomb. This novel is part of the autobiographical hypertext of the writer, contains recognizable autobiographems, it is the artistic reproduction of an episode in her real life. Most of the narrated episodes take place in Japan. The main plot is built upon the love story between a French-speaking Belgian girl and a Japanese boy. The main characters of the novel appear as atypical representatives of their national traditions; the girl of Belgian origins is in love with Japan and its culture, as well as the Japanese man prefers European traditions. Through their tastes these two main characters get to know each other, as well as their culture, tradition and mindsets. Japanese gastronomic discourse is presented more broadly than the Belgian one. It is represented by the names and descriptions of national Japanese dishes, drinks, Japanese culinary traditions, rituals. Belgian gastronomic discourse is almost absent in the novel, because it fits into a broader European discourse, represented mainly by European international dishes. The gastronomic discourse of the novel is a means of characterizing the protagonists, their psychological and social portrait. The mixing of gender and social roles of the characters is shown through the tastes. Gastronomic images become memory boosters, causing the 'effect of a madeleine cookie by Marcel Proust'.
\end{abstract}

Keywords: gastronomic discourse, gastronomic images, national gastronomic images, intercultural communication, autobiographical discourse, Japanese culinary traditions.

\section{INTRODUCTION}

Problem statement. Food culture is an integral part of everyday life, so culinary traditions become 'individual marker' of every nation. This specific feature of each culture is underlined in the literary works of francophone writers, who have always shown a special love for the use of gastronomic motifs and images from the very beginning of the existence of French novel. The relevance of the literary study of gastronomic images is due to the need to investigate causes, manifestations and meanings of the particular interest in gastronomic discourse of francophone writers, on the one hand, and the insufficient level of research of the gastronomic discourse on the material of modern novels, on the other. The relevance of our study lies primarily in saturation of modern francophone novels with gastronomic motifs and images that acquire important shades of meaning and numerous connotations, they become a means for character development, representation of national traditions, means of intercultural communication.

The objective of the article. To research the functioning of gastronomic images in $\mathrm{Ni}$ Ève, ni Adam by Amélie Nothomb, modern Belgian Frenchspeaking writer; to examine the novel from the perspective of its intercultural communication context as well.

\section{LITERATURE REVIEW}

The problem of functioning of gastronomic images in fiction is actual in the modern scientific space as Fritz Allhoff and Dave Monroe [1], Svitlana Kovpik [2], Ganna Satanovska [3] dedicate their studies to it. In the monograph The Sacred and the Profane by 
Mircea Eliade the author accentuates that in mythological world perception there is identification of the human body with the cosmos and the home as the 'gates' of a higher order [4, p. 109]. Elena Samodelova examines the gastronomic images in the context of corporality, accentuating their cosmogonical origins [5, p. 2]. Olga Freidenberg points out that the food is the central act in the life of the society that is experienced cosmogonically, in the act of eating, the cosmos disappears and appears, and the very act of tearing and gnawing symbolizes the act of immortality (salvation from death, resurrection), as well as the merging of man and space. Thus, the gastronomic images become a point of intersection of motives in the structure of the artistic work and begin to perform sense-creating and plot-creating functions $[6$, p. 65]. Mikhail Bakhtin accentuates that in the act of eating the boundaries between the body and the world are overcome in a positive sense for the body: it conquers the world by absorbing one of its parts and grows at its expense. Mikhail Bakhtin emphasizes that food in the ancient system of images has always been associated with work, it is the result of work, a sign of human victory over the world. From this always comes the cheerful connotation of a feast because a feast celebrates victory based on its very nature - a banquet celebration has a universal character, symbolizing the victory of life over death [7, pp. 307-309].

The intercultural studies are the subjects of the detailed consideration by Paul W. James [8], Lustig W. Myron and Jolene Koester [9], G. Schiewer [10].

The creative work by Amélie Nothomb is the object of study by Lorelin Amanieux [11], Susan Bainbridge and Janet den Thunder [12], Genevieve de Klerk [13], Mark D. Lee [14], Tetiana Cherkashyna [15], Mariia Belyavskaya [16] as well.

The majority of the present scientific studies on autobiographical works by Amélie Nothomb deal uppermost with examining the author's most known autobiographical novel Fear and Trembling (Stupeur et tremblements, 1999) and with researching the problems of I/Others and 'one's own'/'stranger'. These studies trace the correlation of the Eastern (Japanese) and the Western in the writer's life and autobiographical works. Gastronomic images have been studied through the concept of HUNGER (look [17]). However, the aspect of gastronomic images in autobiographical works by Amélie Nothomb has not until now been examined as a mean of modelling space and time structure of the novel and as a method of intercultural experience of one another by a woman and a man.

\section{MATERIALS AND METHODS}

Ni Ève, ni Adam, autobiographical novel by Amélie Nothomb, modern French-speaking writer, served as research material. The novel was published in Albin Michel Parisian publishing house in 2007. Methods of researching the text are biographical, hermeneutic, and comparative.

\section{RESULTS AND DISCUSSIONS}

The novel Ni Ève, ni Adam was published in 2007. It is a logical continuation of a fictionalized autobiographical story, when young Amélie Nothomb, after graduating from the Free University of Brussels, returned to Japan to work for a large Japanese company. This episode was reproduced in her most famous novel Stupeur et tremblements. Among other Tokyo adventures, in the novel Stupeur et tremblement Amélie Nothomb mentioned her love story with the Japanese boy Rinri, whom she taught French. Afterwards this very episode from the writer's life was detailed in the novel $\mathrm{Ni} \grave{E} v e$, ni Adam.

The main characters of the novel are a young Belgian girl Amélie, who came to Japan on a contract to work in a large corporation. Japan - the country of her heart because it was here that she lived the first five years of her happy life. Her father, a Belgian diplomat baron Patrick Nothomb, worked in Japan at that time, so the family lived in Kansai, Amélie had a Japanese nanny, went to a Japanese kindergarten, and spoke Japanese in addition to her native French. And quite often in her autobiographical novel, she mentioned that she felt Japanese, although the Japanese environment she lived in did not accept her, reminding her on many occasions of her non-Japanese origins.

Later, the family of the diplomat Patrick Nothomb changed many diplomatic missions, one after another, moving to several different countries (Japan, China, Laos, Bangladesh, the USA), changing languages, cultures, national environment. The only thing that never changed that in these new places Amélie was always the only Belgian girl:

"J'étais, comme toujours dans ma vie, l'unique Belge" [18, p. 16].

Because of numerous relocations and constant changes in a non-national environment, Amélie is open to other cultures, to other traditions (although she does not always understand or accept them). Despite the kaleidoscopic change of residence, Japan has forever entered her heart, so she constantly returns to 
it in her autobiographical work (for more details on the Tokyo text of the writer [19], [20], [21]).

Therefore, one the protagonists of the novel, Rinri, is a typical Japanese guy from a respectable family. As Amélie Nothomb presented him at the beginning of the novel:

“Je posai des questions et appris qu'il avait vingt ans, qu'il s'appelait Rinri et qu'il étudiait le français à l'université. $<\ldots>$. Lui était originaire de Tokyo, où son père dirigeait une importante école de joaillerie" [18, pp. 4-5].

Amélie's love for this guy becomes inseparable from her boundless love for Japan, although she never risked staying with him in Japan forever, choosing the path of a free life, without boundaries (neither external nor internal).

The first acquaintance of the main characters takes place in one of Tokyo's cafes, where there are always many foreigners among the visitors, so the whole novel Ni Ève, ni Adam centers around gastronomic themes, national, foreign, Japan, Japanese, Belgium, Belgian, French and gastronomic images become an indispensable component of the love story of Amélie and Rinri, a bridge between cultures, national traditions, mentalities, a means of communication.

The international cafe, as the place of the characters' first date, was not chosen by chance. An open noisy space in which you can easily blend into the crowd and be invisible to others. All visitors are similar to each other, calmly drink coffee. It is easy to make first contacts in this environment. However, the protagonists of the novel - Amélie and Rinri immediately face the problem of choosing a language for communication. Their first conversation takes place in English. During the conversation, the characters find out that Amélie is a French-speaking girl who can remember very few Japanese words from her childhood; Rinri, in his turn, is fluent in Japanese and speaks French uncertainly with many mistakes. Since Amélie decided to teach Rinri French, this language was chosen as the main means of communication. From time to time the girl switches to Japanese, which became an effective way to remove psychological barriers:

"Je conversai en français afin de connaître son niveau: il se révéla consternant. $<\ldots>$ Le jeune homme devait se rendre compte de la situation car il ne tarda pas à s'excuser, puis à se taire. Je ne pus accepter cet échec et tentai de le faire parler à nouveau. En vain. Il gardait sa bouche close comme pour cacher de vilaines dents. Nous étions dans une impasse. Alors, je me mis à lui parler japonais" [18, pp. 4-5].

The intertwining of languages and cultures becomes a mainstream throughout the novel. Amélie is proud of her Japanese childhood, that she is a Belgian French-speaking girl who knows certain features of the Japanese culture, remembers the language and the gastronomy of the country. Sometimes the gastronomic memory gives her interesting discoveries that surprise her Japanese friends, as it was during the party where Rinri invited her at the beginning of their acquaintance:

"Rinri pelait du gingembre, Hara épluchait des crevettes, Masa avait fini d'atomiser le chou. J'additionnai dans ma tête ces données avec la sauce d'Hiroshima et m'écriai, coupant Amy au milieu d'une phrase sur Portland: - Nous allons manger de l'okonomiyaki!" [18, p. 13].

The mention of this Japanese dish, known to her since her first stay in this country, carried her thoughts to Kansai, to her childhood, a happy and unforgettable time, thus causing the 'effect of a madeleine cookie by Marcel Proust':

"Je contemplai la préparation de la pâte à crêpes, puis la cuisson des okonomiyaki. Cette odeur de chou, de crevettes et de gingembre grésillant ensemble me reporta seize années en arrière, à l'époque où ma douce gouvernante Nishio-san me concoctait le même régal, que je n'avais plus jamais remangé depuis" [18, p. 14].

The smell and taste of this popular Japanese dish intensified not only her gastronomic memory, but also her nostalgia. Amélie mentally finds herself in Japan of her childhood, she is five years old again, she is staying out of the way of her Japanese nanny, watching the process of cooking this simple Japanese dish, inhaling all the fragrances and expecting some unforgettable taste sensations.

Another gastronomic image that evoked lasting childhood memories of the main character was Hiroshima sauce:

"Rinri ouvrit la brique de sauce d'Hiroshima en suivant les pointillés et la posa au centre de la table basse. «What's that?» gémit Amy. Je saisis le carton et respirai avec nostalgie ce parfum de prune amère, de vinaigre, de saké et de soja. J'avais l'air de me droguer au tétrapack" [18, p. 14].

The characters couldn't taste almost any food without it, as it was specially sent for to Hiroshima, because it was only there that it was prepared with the 
perfect recipe. This did not surprise Amélie who used to buy everything she needed in the nearest supermarket, since she knew that Japan had its own traditions, including the cooking ones. And tradition can't be find in the nearest supermarket.

The main chronotope of the novel is that of Japan of the late XX century. Besides the main topos of Tokyo (against the background of which the events unfold), the chronotope of Japan is represented by different locations - Hakone, Hiroshima, Niigata, mounts Fuji and Kumotori Yama, Sado island (where the loving couple travelled at the weekends). Thus, the space and time of the novel is represented by gastronomic images and uppermost by Japanese dishes, which accentuate both temporal model of the novel (the main character's different periods of life) and the spatial one (the space of Japanese locations and the characters' corporal space).

In the text of the novel the main character Amélie gladly describes every Japanese dish she tastes, and every time she remembers her Japanese childhood. For her, the immersion in the Japanese culinary discourse becomes, on the one hand, a means of self-knowledge. From time to time, she tries to solve her personal life dilemma and to understand who she is: a European girl of Belgian origin (because her family comes from Belgium) or a Japanese girl (because in Japan she spent her first five years of life, when her personality developed). On the other hand, it is a way of knowing the culture of her beloved one. She is proud to understand the national, cultural, and mental peculiarities of the country of the guy she loves and who she may cast her future life with.

No Japanese gastronomic image is overlooked except for the already mentioned okonomiyaki (which the heroine has identified as her favourite local dish), she does not miss kori (“j'adorais ces glaces pilées arrosées d'un sirop au thé de cérémonie" [18, p. 26]), "beignets de pissenlits, feuilles de chiso farcies aux racines de lotus, fèves confites aux cédrats, crabes nains frits à croquer entiers" [18, p. 73], kaiseki, bouillon d'orchidées, "nouilles de sarrasin, haricots sucrés, gâteaux de riz et autres bizarreries qui plaisaient plus aux yeux qu'à la bouche" [18, p. 114]. And each time the author provides extensive explanations about the components, appearance, taste and olfactory features, the tradition of consumption of these national dishes, not always known outside of Japan:

"Celui-ci débarrassa les bols de consommé de catleya et les remplaça, pour ma plus grande frustration, par des ramequins individuels de chawan mushi, et moi qui vendrais père et mère pour ce flan de fruits de mer et de champignons noirs au fumet de poisson qu'il faut manger brûlant, je sus que je ne pourrais en avaler une bouchée" [18, p. 75].

Thus, the novel becomes a kind of gastronomic guide to Japanese gastronomic images, better known to the local population than to foreigners visiting the country.

It is notable that the world's most famous Japanese gastronomic images, sushi and sashimi, are mentioned in only one episode of the novel when Amélie asks her beloved why he never cooks or orders them, and he answers that they annoy him terribly because it is a necessary component of family gastronomic gatherings and when they are on the table, he always feels a strong associations with his large family at the table, where he always has to be a polite and obedient boy who has to eat only healthy food. And his refusal of sushi and sashimi in the presence of his beloved girlfriend is a kind of rebellion against everything Japanese around him that reminds him of his upbringing.

During their dates, Rinri always chooses something non-Japanese, preferring fondue, spaghetti carbonara, Italian-American salami, mayonnaise, Chinese noodles and non-local drinks, and this is very surprising to Amélie, who, in her turn, always chooses only Japanese dishes. After a while, Amélie discovers that Rinri is not exactly a typical Japanese guy:

"Il allait de soi qu'une étrangère se réjouirait de ce raffinement japonais alors que lui, il en avait soupé, des nipponeries" [18, p. 20].

The most mentioned drinks in the novel are the traditional Japanese green tea, which Amélie and her beloved man as well as his parents constantly treat; beer - a favourite drink of Rinri and his friends; from time-to-time they order coffee or cola at the cafe and this is a means to emphasize internationality.

Belgian cuisine, despite the Belgian origins of the main character, is left out by the writer. The novel $N i$ Eve, ni Adam is the protagonist's knowledge of the culture, traditions (including gastronomic ones) of the Japanese people, the rediscovery of her cherished Japan, trying to understand mental characteristics of her beloved boyfriend, who can spend hours picking three ginger roots or traveling many kilometres to another city just to buy a few bottles of sauce, because in that city he can find the best recipe.

Several episodes of the novel are devoted to the process of cooking and eating - twice during parties 
with friends organized by Rinri and Amélie, several times during the meetings of the main characters in the apartment of Amélie's friend. And every time the cooking process is a prerogative of the boys, the girls just watch them cooking.

In most national traditions, it is women who are responsible for arranging family life, caring for and raising children, and preparing and serving food. This was originally due to the patriarchal way of life in society when women did not have such opportunities for self-realization as men. Women did not receive such education as men did, as they stayed mostly at home, depending both psychologically and financially on men. Therefore, the home space, including the kitchen, belonged to a purely female territory, where men came only to eat food. And these social stereotypes are still deeply embedded in many societies. It is a woman in most cultures who cooks, serves food at home, taking care of the well-being of the family. Women's cuisine is associated with home, boundless love, a special atmosphere of family comfort and warmth. It is not considered as refined as the 'haute' cuisine of male chefs of restaurants, but it has its own magic and charm, it is simple, unpretentious, but very tasty.

Going back to her childhood, Amélie often mentions that for her, the process of home cooking is strongly associated with her Japanese nanny, whom she loved very much. It was her nanny who introduced her to the magical world of flavours and unusual for a European girl combination of tastes of Japanese cuisine, which remained in her memory for many years:

“J'avais cinq ans, je n'avais jamais quitté les jupes de Nishio-san et je hurlais, le cœur déchiré et les papilles en transe. Je ratiboisai mon okonomiyaki, les yeux dans le vague, en poussant des râles de volupté" [18, pp. 14-15].

Instead, men's cuisine is always strongly associated with professional culinary business. Men are traditionally considered to be the best professional chefs. It was the men who prepared and served food to kings and emperors, it was the male chefs who are still involved in serving high diplomatic receptions, working in the world's best restaurants. Women in the field of professional cooking have traditionally played a purely supporting role, participating in the process of preparation for cooking, cleaning, washing ingredients, cleaning after the cooking process.

Initially, this was due to the fact that professional cooking has for centuries been considered a profession to be learned (and education was not always available to women equally with men). A professional cook necessarily had to know very well the right combinations of ingredients in a recipe, the technological processes in the preparation of a dish, the behaviour of the ingredients during cooking, the characteristics of an adequate presentation, the way to enhance not only the olfactory sensations, but also the visual ones.

The novel $N i$ Ève, ni Adam presents a completely different model of the gender distribution of women and men in the kitchen. Throughout the novel, Amélie only eats food and, as she herself admits, the best she can do is to heat up ready-made food in a microwave oven or open trays with ready-made meals. She is a modern feminist girl who has never been interested in household chores, in none of her autobiographical novels she shows any interest in the cooking process, she never cooks. There are many mentions that in her childhood a Japanese nanny cooked for her, but Amélie just watched it and then tasted her simple, popular, but incredibly tasty dishes.

Immediately after meeting Rinri, it is he who cooks at home for both. Amélie does not participate neither in the cooking nor in preparing the ingredients. Rinri buys the ingredients, cooks, and serves the dishes. "C'était Rinri qui préparait les repas" [18, p. 41] mentioned Amélie, telling the story of their love.

Amélie loves him, idealizes him as the best representative of the Japanese people, often attributes certain national stereotypes to him, comparing him to the samurai.

She fondly observes the technological processes, how attentively he treats every small detail in his cooking activity. She is especially amused by how seriously he takes kitchen utensils, turning ordinary, routine things into real rituals:

"Je devais peu à peu découvrir le culte que vouent les Japonais au matériel destiné à chaque action de la vie : le matériel pour la montagne, le matériel pour la mer, le matériel pour le golf et, ce soir, le matériel pour la fondue suisse. Chez Rinri, il y avait une pièce bien rangée où des valises étaient déjà prêtes pour ces diverses opérations" [18, p. 28].

In the novel there are several ironic descriptions of the 'samurai' and his tools, such as when Amélie describe how Rinri prepared fondue on one of their first dates:

"Devant mes yeux fascinés, le jeune homme ouvrit la valise spécifique et je vis apparaître, disposés 
d'inamovible façon, un réchaud à propulsion intergalactique, un caquelon anti-adhésif, un sachet de fromage en polystyrène expansé, une bouteille de vin blanc antigel et des croûtons de pain imputrescible. $<\ldots>$ Il versa le polystyrène et l'antigel dans le caquelon, alluma le réchaud qui, curieusement, ne décolla pas vers le ciel et, pendant que ces substances provoquaient ensemble diverses réactions chimiques, sortit de la valise des assiettes se voulant tyroliennes, de longues fourchettes et des verres à pied" [18, pp. 28-29].

Amélie is amused by this, she finds it funny, but at the same time she is fond of it, and her feelings take origin not only in the love for her boyfriend but also, more generally, in the boundless love for Japan and all Japanese things.

Sometimes she ironically notices every detail of her beloved's serious and responsible attitude to whatever he does and in her descriptions, she always underlines that his diligence, his attention to detail, his careful attitude to ceremonies and rituals are all typical features of the Japanese people. That is why, even when he goes out for a regular family picnic, Rinri takes a long and carefully prepared suitcase with everything needed for entertainment:

"Rinri prit dans le coffre une valise qui se révéla celle des feux d'artifice, de même qu'il y avait eu la valise de la fondue suisse. Il disposa sur le sol un matériel d'artificier et nous avertit que cela allait commencer. $<\ldots>$ Il prit dans la valise des fagots de brindilles et nous en distribua par poignées. Il n'en alluma qu'une qui propagea l'incendie à toutes les extrémités. Chaque baguette émit son faisceau d'étincelles tournoyantes" [18, p. 48].

However, the novel $N i$ Eve, ni Adam breaks the stereotype that the best chefs are men. Despite all the careful preparations and the 'samurai' collection of accessories, according to the main character "Il cuisinait mal, mais mieux que moi, ce qui est le cas de l'humanité entière" $[18$, p. 41].

In this endless gastronomic discourse of the novel, Amélie chooses the role of a girl in love with a Japanese guy and with Japan in general, who does nothing but eat, enjoying the tastes familiar to her since childhood, of the combinations of ingredients often very original.

Unlike the serious and concentrated 'samurai' Rinri, she is completely free to express her emotions and feelings, so she expresses them freely, without thinking about the reaction of others to her actions. With a certain amount of irony, she describes her constant transformations from a European, wellmannered, and polite girl into a real savage, as soon as it comes to something delicious, known from her childhood:

"Quand je reçus mon assiette de crêpe farcie, je perdis mon vernis de civilisation, arrosai de sauce sans attendre personne et attaquai. $<\ldots>$ Ce fut quand j'eus tout mangé que je vis les autres me regarder avec une gêne polie. - $\grave{A}$ chaque pays ses manières de table, balbutiai-je. Vous venez de découvrir les Belges" [18, pp. 14-15].

Rinri, in his turn, is the exact opposite: always restrained, he clearly controls his emotions and is more often a spectator of how Amélie eats food, and this process of onlooking the 'savage' is one of the ways for him to learn about another culture, another mentality, different gastronomic traditions.

\section{CONCLUSIONS}

The gastronomic imagery of $\mathrm{Ni}$ Eve, ni Adam by Amélie Nothomb is represented by different dichotomies: to model the text from a space-time point of view, the author uses the temporal dichotomy 'Past / Present' and the spatial dichotomy 'Protagonist / Other'. For modelling the cross-cultural level of the text, she uses the dichotomies "national food/ food belonging to another nation'; 'women's/ men's kitchen'.

The gastronomic images are temporal markers as they provoke the 'effect of a madeleine cookie by Marcel Proust', making the protagonist return to her childhood times.

Japanese national gastronomic images become not only a means of characterizing the space and time structure of the text, but also, they are the means for making experience of the local culture and traditions. Gastronomic experience allows the protagonist to know better herself and the people she loves.

The gastronomic images are a means of describing the characters: through gastronomic images it becomes possible to model their psychological and mental portrait or their relationship.

The gastronomic imagery related to the characters is able to break down national, gender, social and cultural stereotypes.

\section{REFERENCES}

[1] F. Allhoff, D. Monroe, Food and Philosophy: Eat, Think, and Be Marry, Wiley-Blackwell, 2007. 
[2] S. Kovpik, Poetics of tastes, NVP Interservice, 2018.

[3] G.S. Satanovska, Poetics of tastes in the spatial model of the novel by Marguerite Yourcenar's Philosopher's Stone, Scientific Proceedings of Ostroh Academy National University: Philology Series 52 (2015) 235-237.

[4] M. Eliade, Sacred and secular, Osnovy, 2001.

[5] E.A. Samodielova, S. A. Esenin's anthropological poetics: author's life text at the crossroads of cultural traditions, 2008.

[6] O.M. Freidenberg, Poetics of plot and genre, Labirint, 1997.

[7] M.M. Bakhtin, Forms of time and chronotop in the novel. Essays on historical poetics, in: Questions of literature and aesthetics. Studies of different years, Khudlit, 1975, pp. 234-407.

[8] P.W. James, Globalism. Nationalism. Tribalism, SAGE Publications, 2006.

[9] L.W. Myron, J. Koester, Intercultural Competence: Interpersonal Communication Across Cultures, Pearson, 2010.

[10] G. Schiewer, Contemporary Literature and Intercultural Understanding, in: The Cambridge Handbook of Intercultural Communication, 2020, pp. 261-275. DOI: $10.1017 / 9781108555067.019$.

[11] L. Amanieux, Amélie Nothomb, l'éternelle affamée, Albin Michel, 2005.

[12] S. Bainbrigge, J.M.L. Toonder (Eds.), Amélie Nothomb Authorship, Identity and Narrative Practice, Peter Lang Publishing, 2003.

[13] G. de Clerck, Le dialogue hypermoderne d'Amélie Nothomb ou La poétique d'un sabotage, Pro QuestLLC, 2006.

[14] M.D. Lee, Les identities d'Amélie Nothomb: de l'invention médiatique aux fantasmes originaires, Rodopi, 2010.

[15] T. Cherkashyna, Search for personal identity in the Amélie's Nothomb autobiographical novels, Bulletin of Zaporizhzhia National University: Philological Sciences 1, part 2 (2020) 167-172. DOI: https://doi.org/10.26661/2414-9594-20201-2-23.

[16] M. Belyavskaya, Ideological and artistic world in the novel by $\mathrm{A}$. Nothomb Métaphysique des tubes, Accents and Paradoxes of Modern Philology 1 (3) (2018) 31-43. DOI: https://doi.org/10.26565/2521-6481-2018-3-2.

[17] H. Jaccomard, Le fabuleux destin d'Amélie Nothomb, in: Les Nouvelles Autobiographies, vol. 42, No. 4, The Johns Hopkins University Press, 2002, pp. 45-57.

[18] A. Nothomb, Ni Ève, ni Adam, Albin Michel, 2007.

[19] J.-M. Lou, Le Japon d'Amélie Nothomb, L'Harmattan, 2011.

[20] K. Koma, L’Univers “Japon” romanesque en tant que scénographie dans Stupeur et Tremblement d'Amélie Nothomb, Literatura 51 (4) (2009) 7383.

[21] P. Szczur, Du roman exotique à l'interprétation (dés)exotisante: les romans "japonais" d'Amélie Nothomb et leurs lectures, Roczniki Humanistyczne LXV (5) (2017) 109-124. DOI: http://doi.org/10.18290/rh.2017.65.5-7. 